Editorial

\title{
Stem Cells in Equine Veterinary Practice-Current Trends, Risks, and Perspectives
}

\author{
Katarzyna Kornicka ${ }^{1,2}$, Florian Geburek ${ }^{3}$, , Michael Röcken ${ }^{3}$ and Krzysztof Marycz ${ }^{1,2,3, *(1)}$ \\ 1 Department of Experimental Biology, The Faculty of Biology and Animal Science, \\ University of Environmental and Life Sciences, 50-375 Wroclaw, Poland; kornicka.katarzyna@gmail.com \\ 2 International Institute of Translational Medicine, Malin, Jesionowa 11, 55-114 Wisznia Mała, Poland \\ 3 Faculty of Veterinary Medicine, Equine Clinic-Equine Surgery, Justus-Liebig-University, 35392 Giessen, \\ Germany; florian.geburek@vetmed.uni-giessen.de (F.G.); michael.roecken@vetmed.uni-giessen.de (M.R.) \\ * Correspondence: krzysztofmarycz@interia.pl; Tel.: +71-320-5248
}

Received: 6 May 2019; Accepted: 7 May 2019; Published: 14 May 2019

\begin{abstract}
With this Editorial, we introduce the Special Issue "Adipose-Derived Stem Cells and Their Extracellular Microvesicles (ExMVs) for Tissue Engineering and Regenerative Medicine Applications" to the scientific community. In this issue, we focus on regenerative medicine, stem cells, and their clinical application.
\end{abstract}

Keywords: adipose derived stem cells; extracellular microvesicles; regenerative medicine

Recently, stem cell-based therapies have been widely applied in the equine veterinary field [1]. For more than a decade, the transplantation of autologous mesenchymal stem cells (MSCs) has been investigated in multiple experimental and clinical animal trials worldwide [2]. MSCs have been shown to have positive effects in the treatment of musculoskeletal, neurodegenerative, metabolic, and immune diseases [3]. The clinical application of MSCs has raised hope for a more effective treatment of tendon and articular diseases, which are the most common musculoskeletal disorders in horses [4]. The unique properties of MSCs, i.e., multipotency, proliferative, and clonogenic potential and paracrine action, make them an innovative tool for improved repair or even potential regeneration of damaged tissue [3]. During the last 20 years, several research groups have investigated various aspects of MSC biology in the context of their clinical usefulness. MSCs can be isolated from multiple tissue sources, but most attention has been paid to cells isolated from bone marrow (BM-MSCs), adipose tissue (AT-MSCs/ASCs), Wharton's jelly (WJMSCs) [5], and, more recently, blood [6]. The source selection of the stem cells depends on both ease of access and of harvesting, the need for local or general anesthesia, and, finally, yield and quality of the isolated cells. Further research by molecular biologists has focused on cytophysiological aspects of MSCs: their metabolic activity, presence of particular surface antigens, gene expression profile, and proteomics. Adult MSCs from diverse sources behave in predictable ways, which offer promise in terms of their clinical applications [7]. Early publications showed the beneficial effects of autologous ASCs and BMSCs transplantation on tendinopathies of the equine superficial digital flexor tendon [8,9]. For example, it was shown that autologous ASCs enhance perfusion and neovascularization of healing experimental tendon lesions in horses [10]. Recently, other studies have delivered clinical evidence that autologous MSCs applied by intralesional injection, intravenously, and, more recently, intraarterially, can be an effective therapeutic approach in the treatment of tendinopathies when compared with conventional treatments, e.g., anti-inflammatory drugs [11-14]. However, the effect of a single intralesional treatment with autologous MSCs has proved to be limited in an equine experimental model of tendinopathy [15]. Several studies have investigated the effects of MSCs combined with platelet rich plasma (PRP) or other blood-based substrates to improve the clinical outcome and prolong therapeutic effects [16,17]. After years of MSC research, there remain 
discrepancies between promising experimental in vitro and in vivo results and evidence-based safety as well as clinical effectivity of such therapies. Multiple factors affect MSCs properties, including their niche, which may reduce their therapeutic potential [18-21]. Current molecular studies have revealed that the regenerative potential of MSCs strongly depends on the age and metabolic condition of a patient, including insulin resistance [22,23]. Time and temperature of MSC shipment as well as application technique are crucial for its viability [24]. However, specific data regarding these factors is lacking in the literature. The development of a "passport" for stem cells that describes their physiological condition prior to their clinical application is crucial to standardize the procedure. This document should include information regarding the source of the MSCs as well as phenotype, proliferative potential, apoptotic genes expression, clonogenic potential, multipotency, as well as the time and temperature of shipment and storage before clinical application of the cells. The description of these factors should be a minimum requirement before cell transplantation.

Autologous MSCs transplantation will never be a true "off the shelf" therapy because it requires time for cell isolation, additional laboratory work, and, most importantly, a minimum of 10 days of propagation in vitro to obtain the number of MSCs estimated to be adequate for clinical application [25]. MSCs were previously thought to be immune privileged and considerable attention has been paid towards allogenic therapies in equids and other mammals [26,27]. The perspective of immediate application of MSCs was attractive to the veterinary community because it allowed for patient treatment without loss of time or risk of disease progression. Lack of MHC II in MSCs was proved in multiple studies; thus, MSCs are considered safe in cases of allogeneic administration [28]. However, there have been several reports of adverse clinical events in equine models [29,30]. Modification of culture condition, a 48-hour depletion culture period of fetal bovine serum (FBS), greatly eliminates the risk of adverse effects [30]. Another option may be ex vivo adaptation of MSCs in autologous serum-supplemented medium prior to application [31]. The strategy to apply allogeneic MSCs is attractive from a clinical perspective; however, a proper cell culture method is required to eliminate potential risk.

Stem cells therapies in equine veterinary practice have been mostly applied for the treatment of disorders of the musculoskeletal system [2,32]. However, recent data has shown that MSCs are potentially effective in the treatment of other diseases in equids including insulin resistance (IR) [33,34]. Several studies have shown that both obesity and IR negatively affect multipotency of MSCs through impairment of autophagy, a process which allows stem cells to remove dysfunctional organelles and regenerate [35-38]. It has been shown that ASCs derived from IR horses are characterized by elevated oxidative stress and aged phenotype which may disqualify them for clinical application [37]. Therefore, it is necessary to rejuvenate impaired autologous MSCs prior to clinical application. Several chemicals with antioxidative and anti-aging properties have been proposed as rejuvenating agents; these include 5 -azacytidine (demethylation agent) and resveratrol (polyphenol). It has been shown that a combination of these substances successfully reverses the aged nature of ASCs derived from IR horses [39-41]. This phenomenon may contribute to the development of a new branch in veterinary pharmacotherapy, i.e., stem cell pharmacology. In the near future, pre-treatment of MSCs with pharmacological substances will likely become a common procedure for the modulation of cytophysiological properties of stem cells before their clinical application.

Initially, the hypothesis behind MSC therapy suggested that viable cells integrate in the tissue defect to replace it. Although it could be shown experimentally that high numbers of MSCs remained in and near equine experimental tendon lesions after local application [42], the percentage of cells injected significantly decreased shortly after application depending on the cell type [43]. Accordingly, the secretome of MSCs and the mechanisms by which it affects damaged tissues has been under intense investigation recently $[44,45]$. Several research groups showed that MSCs secrete a wide range of growth factors, chemokines, and cytokines, which are either released into intercellular space or transported in extracellular membrane-derived microvesicles (ExMVs) to neighboring cells [46]. Recently, it was shown that ExMVs cargo also contains miRNAs, which indirectly or directly modulate 
gene expression in recipient cells of damaged tissue [47]. Evidence suggests that the secretomes of MSCs constantly promote regeneration of damaged tissue by various mechanisms, including inhibition of apoptosis, promotion of cell survival, and, most importantly from a clinical perspective, exertion of immunomodulatory effects [48]. Moreover, the secretomes of MSCs promote neurogenesis and angiogenesis, which may be fundamental in the course of the regenerative process because "there is no regeneration without vascularization" [49]. Thus, future research in equine regenerative medicine should focus on the regeneration of damaged tissue by the application of MSCs secretomes or their elements because, unlike allogenic MSCs, they are not expected to cause any side effects. On the basis of recent findings, one might speculate that the application of MSCs secretomes might become a useful therapeutic tool in equine regenerative medicine in the near future.

Stem cells have brought new hope for veterinary regenerative medicine and are becoming an increasingly promising clinical tool. However, many questions remain unanswered, including the justifiability of allogenic stem cell application or the clinical utility of MSCs isolated from individuals diagnosed with certain disorders. There are strong requirements justifiable for further consolidation grants to elaborate exact protocols for the molecular and physiological characteristics of MSCs prior to MSCs-based experimental and clinical animal trials as well as, ultimately, routine clinical application.

Author Contributions: K.K., F.G., M.R., K.M. formal analysis; K.K., F.G., M.R., K.M. writing一original draft preparation; K.K. writing — review and editing; K.M. project administration, K.M. funding acquisition.

Funding: This project was financed within the framework of a grant entitled "Modulation mitochondrial metabolism and dynamics and targeting DNA methylation of adipose derived mesenchymal stromal stem cell (ASC) using resveratrol and 5-azacytydin as a therapeutic strategy in the course of Equine metabolic syndrome (EMS)" (grant no. 2016/21/B/NZ7/01111) and "Inhibition of tyrosine phosphatase as a strategy to enhance insulin sensitivity through activation of chaperone mediated autophagy and amelioration of inflammation and cellular stress in the liver of equine metabolic syndrome (EMS) horses" (grant no. 2018/29/B/NZ7/02662), both of which were financed by The National Science Centre in Poland.

Conflicts of Interest: The authors declare no conflict of interest.

\section{References}

1. Fortier, L.A.; Travis, A.J. Stem cells in veterinary medicine. Stem Cell Res. Ther. 2011, 2, 9. [CrossRef] [PubMed]

2. Markoski, M.M. Advances in the use of stem cells in veterinary medicine: From basic research to clinical practice. Scientifica 2016, 2016, 4516920. [CrossRef] [PubMed]

3. Wei, X.; Yang, X.; Han, Z.; Qu, F.; Shao, L.; Shi, Y. Mesenchymal stem cells: A new trend for cell therapy. Acta Pharmacol. Sin. 2013, 34, 747-754. [CrossRef]

4. Bertuglia, A.; Bullone, M.; Rossotto, F.; Gasparini, M. Epidemiology of musculoskeletal injuries in a population of harness Standardbred racehorses in training. BMC Vet. Res. 2014, 10, 11. [CrossRef]

5. Ding, D.-C.; Shyu, W.-C.; Lin, S.-Z. Mesenchymal stem cells. Cell Transplant. 2011, 20, 5-14. [CrossRef]

6. Longhini, A.L.F.; Salazar, T.E.; Vieira, C.; Trinh, T.; Duan, Y.; Pay, L.M.; Li Calzi, S.; Losh, M.; Johnston, N.A.; Xie, H.; et al. Peripheral blood-derived mesenchymal stem cells demonstrate immunomodulatory potential for therapeutic use in horses. PLoS ONE 2019, 14, e0212642. [CrossRef] [PubMed]

7. Caplan, A.I. Mesenchymal stem cells. J. Orthop. Res. Off. Publ. Orthop. Res. Soc. 1991, 9, 641-650. [CrossRef] [PubMed]

8. Richardson, L.E.; Dudhia, J.; Clegg, P.D.; Smith, R. Stem cells in veterinary medicine-Attempts at regenerating equine tendon after injury. Trends Biotechnol. 2007, 25, 409-416. [CrossRef] [PubMed]

9. Smith, R.K.W.; Werling, N.J.; Dakin, S.G.; Alam, R.; Goodship, A.E.; Dudhia, J. Beneficial effects of autologous bone marrow-derived mesenchymal stem cells in naturally occurring tendinopathy. PLoS ONE 2013, 8, e75697. [CrossRef]

10. Conze, P.; van Schie, H.T.M.; van Weeren, R.; Staszyk, C.; Conrad, S.; Skutella, T.; Hopster, K.; Rohn, K.; Stadler, P.; Geburek, F. Effect of autologous adipose tissue-derived mesenchymal stem cells on neovascularization of artificial equine tendon lesions. Regen. Med. 2014, 9, 743-757. [CrossRef] [PubMed]

11. Lombana, K.G.; Goodrich, L.R.; Phillips, J.N.; Kisiday, J.D.; Ruple-Czerniak, A.; McIlwraith, C.W. An investigation of equine mesenchymal stem cell characteristics from different harvest sites: More similar than not. Front. Vet. Sci. 2015, 2. [CrossRef] 
12. Durgam, S.; Stewart, M. Evidence Supporting Intralesional Stem Cell Therapy to Improve Equine Flexor Tendon Healing. Vet. Evid. 2017, 2, 67. [CrossRef]

13. Taylor, S.E.; Smith, R.K.W.; Clegg, P.D. Mesenchymal stem cell therapy in equine musculoskeletal disease: Scientific fact or clinical fiction? Equine Vet. J. 2007, 39, 172-180. [CrossRef]

14. Torrent, A.; Spriet, M.; Espinosa-Mur, P.; Clark, K.C.; Whitcomb, M.B.; Borjesson, D.L.; Galuppo, L.D. Ultrasound-guided injection of the cranial tibial artery for stem cell administration in horses. Equine Vet. J. 2019. [CrossRef]

15. Ahrberg, A.B.; Horstmeier, C.; Berner, D.; Brehm, W.; Gittel, C.; Hillmann, A.; Josten, C.; Rossi, G.; Schubert, S.; Winter, K.; et al. Effects of mesenchymal stromal cells versus serum on tendon healing in a controlled experimental trial in an equine model. BMC Musculoskelet. Disord. 2018, 19, 230. [CrossRef]

16. Del Bue, M.; Riccò, S.; Ramoni, R.; Conti, V.; Gnudi, G.; Grolli, S. Equine adipose-tissue derived mesenchymal stem cells and platelet concentrates: Their association in vitro and in vivo. Vet. Res. Commun. 2008, 32, S51-S55. [CrossRef]

17. Carvalho, A.M.; Badial, P.R.; Álvarez, L.E.C.; Yamada, A.L.M.; Borges, A.S.; Deffune, E.; Hussni, C.A.; Garcia Alves, A.L. Equine tendonitis therapy using mesenchymal stem cells and platelet concentrates: A randomized controlled trial. Stem Cell Res. Ther. 2013, 4, 85. [CrossRef]

18. Nawrocka, D.; Kornicka, K.; Szydlarska, J.; Marycz, K. Basic fibroblast growth factor inhibits apoptosis and promotes proliferation of adipose-derived mesenchymal stromal cells isolated from patients with type 2 diabetes by reducing cellular oxidative stress. Oxid. Med. Cell Longev. 2017, 2017, 3027109.

19. Kornicka, K.; Marycz, K.; Tomaszewski, K.A.; Marędziak, M.; Śmieszek, A. The effect of age on osteogenic and adipogenic differentiation potential of human adipose derived stromal stem cells (hASCs) and the impact of stress factors in the course of the differentiation process. Oxid. Med. Cell. Longev. 2015, 2015, 309169. [CrossRef]

20. Marędziak, M.; Marycz, K.; Tomaszewski, K.A.; Kornicka, K.; Henry, B.M. The influence of aging on the regenerative potential of human adipose derived mesenchymal stem cells. Stem Cells Int. 2016, 2016, 2152435. [CrossRef]

21. Kornicka, K.; Houston, J.; Marycz, K. Dysfunction of mesenchymal stem cells isolated from metabolic syndrome and type 2 diabetic patients as result of oxidative stress and autophagy may limit their potential therapeutic use. Stem Cell Rev. Rep. 2018, 14, 337-345. [CrossRef] [PubMed]

22. Nawrocka, D.; Kornicka, K.; Śmieszek, A.; Marycz, K. Spirulina platensis improves mitochondrial function impaired by elevated oxidative stress in adipose-derived mesenchymal stromal cells (ASCs) and intestinal epithelial cells (IECs), and enhances insulin sensitivity in equine metabolic syndrome (EMS) horses. Mar. Drugs 2017, 15, 237. [CrossRef]

23. Kornicka, K.; Marycz, K.; Maręziak, M.; Tomaszewski, K.A.; Nicpon, J. The effects of the DNA methyltranfserases inhibitor 5-Azacitidine on ageing, oxidative stress and DNA methylation of adipose derived stem cells. J. Cell. Mol. Med. 2017, 21, 387-401. [CrossRef]

24. Barrachina, L.; Romero, A.; Zaragoza, P.; Rodellar, C.; Vázquez, F.J. Practical considerations for clinical use of mesenchymal stem cells: From the laboratory to the horse. Vet. J. 2018, 238, 49-57. [CrossRef]

25. Sensebé, L.; Gadelorge, M.; Fleury-Cappellesso, S. Production of mesenchymal stromal/stem cells according to good manufacturing practices: A review. Stem Cell Res. Ther. 2013, 4, 66. [CrossRef]

26. Teshima, T.; Matsumoto, H.; Michishita, M.; Matsuoka, A.; Shiba, M.; Nagashima, T.; Koyama, H. Allogenic adipose tissue-derived mesenchymal stem cells ameliorate acute hepatic injury in dogs. Stem Cells Int. 2017, 2017, 3892514. [CrossRef]

27. Broeckx, S.; Suls, M.; Beerts, C.; Vandenberghe, A.; Seys, B.; Wuertz-Kozak, K.; Duchateau, L.; Spaas, J.H. Allogenic mesenchymal stem cells as a treatment for equine degenerative joint disease: A pilot study. Curr. Stem Cell Res. Ther. 2014, 9, 497-503. [CrossRef]

28. Chamberlain, G.; Fox, J.; Ashton, B.; Middleton, J. Concise review: Mesenchymal stem cells: Their phenotype, differentiation capacity, immunological features, and potential for homing. Stem Cells 2007, 25, 2739-2749. [CrossRef] [PubMed]

29. Pigott, J.H.; Ishihara, A.; Wellman, M.L.; Russell, D.S.; Bertone, A.L. Inflammatory effects of autologous, genetically modified autologous, allogeneic, and xenogeneic mesenchymal stem cells after intra-articular injection in horses. Vet. Comp. Orthop. Traumatol. 2013, 26, 453-460. 
30. Joswig, A.-J.; Mitchell, A.; Cummings, K.J.; Levine, G.J.; Gregory, C.A.; Smith, R.; Watts, A.E. Repeated intra-articular injection of allogeneic mesenchymal stem cells causes an adverse response compared to autologous cells in the equine model. Stem Cell Res. Ther. 2017, 8, 42. [CrossRef]

31. Haque, N.; Kasim, N.H.A.; Rahman, M.T. Optimization of pre-transplantation conditions to enhance the efficacy of mesenchymal stem cells. Int. J. Biol. Sci. 2015, 11, 324-334. [CrossRef] [PubMed]

32. Gattegno-Ho, D.; Argyle, S.-A.; Argyle, D.J. Stem cells and veterinary medicine: Tools to understand diseases and enable tissue regeneration and drug discovery. Vet. J. Lond. Engl. 2012, 191, 19-27. [CrossRef] [PubMed]

33. Bi, S.; Nie, Q.; Wang, W.-Q.; Zhu, Y.-L.; Ma, X.-M.; Wang, C.-M.; Zhang, B.-C.; Li, H.-Y.; Zhang, Q.; Chen, G. Human umbilical cord mesenchymal stem cells therapy for insulin resistance: A novel strategy in clinical implication. Curr. Stem Cell Res. Ther. 2018, 13, 658-664. [CrossRef] [PubMed]

34. Gao, L.R.; Zhang, N.K.; Zhang, Y.; Chen, Y.; Wang, L.; Zhu, Y.; Tang, H.H. Overexpression of Apelin in Wharton' jelly mesenchymal stem cell reverses insulin resistance and promotes pancreatic $\beta$ cell proliferation in type 2 diabetic rats. Stem Cell Res. Ther. 2018, 9, 339. [CrossRef] [PubMed]

35. Marycz, K.; Kornicka, K.; Grzesiak, J. ; Śmieszek, A; Szłapka, J. Macroautophagy and selective mitophagy ameliorate chondrogenic differentiation potential in adipose stem cells of equine metabolic syndrome: New findings in the field of progenitor cells differentiation. Oxid. Med. Cell Longev. 2016, 2016, 3718468. [CrossRef] [PubMed]

36. Marycz, K.; Kornicka, K.; Marędziak, M.; Golonka, P.; Nicpoń, J. Equine metabolic syndrome impairs adipose stem cells osteogenic differentiation by predominance of autophagy over selective mitophagy. J. Cell. Mol. Med. 2016, 20, 2384-2404. [CrossRef]

37. Marycz, K.; Kornicka, K.; Basinska, K.; Czyrek, A. Equine metabolic syndrome affects viability, senescence, and stress factors of equine adipose-derived mesenchymal stromal stem cells: New insight into EqASCs isolated from EMS horses in the context of their aging. Oxid. Med. Cell Longev. 2016, 2016, 4710326. [CrossRef]

38. Marycz, K.; Kornicka, K.; Szlapka-Kosarzewska, J.; Weiss, C. Excessive endoplasmic reticulum stress correlates with impaired mitochondrial dynamics, mitophagy and apoptosis, in liver and adipose tissue, but not in muscles in EMS horses. Int. J. Mol. Sci. 2018, 19, 165. [CrossRef]

39. Kornicka, K.; Szłapka-Kosarzewska, J.; Śmieszek, A.; Marycz, K. 5-Azacytydine and resveratrol reverse senescence and ageing of adipose stem cells via modulation of mitochondrial dynamics and autophagy. J. Cell. Mol. Med. 2019, 23, 237-259. [CrossRef]

40. Kornicka, K.; Śmieszek, A.; Węgrzyn, A.S.; Röcken, M.; Marycz, K. Immunomodulatory properties of adipose-derived stem cells treated with 5-azacytydine and resveratrol on peripheral blood mononuclear cells and macrophages in metabolic syndrome animals. J. Clin. Med. 2018, 7, 383. [CrossRef]

41. Marycz, K.; Kornicka, K.; Irwin-Houston, J.M.; Weiss, C. Combination of resveratrol and 5-azacytydine improves osteogenesis of metabolic syndrome mesenchymal stem cells. J. Cell. Mol. Med. 2018, 22, 4771-4793. [CrossRef] [PubMed]

42. Geburek, F.; Mundle, K.; Conrad, S.; Hellige, M.; Walliser, U.; van Schie, H.T.M.; van Weeren, R.; Skutella, T.; Stadler, P.M. Tracking of autologous adipose tissue-derived mesenchymal stromal cells with in vivo magnetic resonance imaging and histology after intralesional treatment of artificial equine tendon lesions-A pilot study. Stem Cell Res. Ther. 2016, 7, 21. [CrossRef] [PubMed]

43. Guest, D.J.; Smith, M.R.W.; Allen, W.R. Monitoring the fate of autologous and allogeneic mesenchymal progenitor cells injected into the superficial digital flexor tendon of horses: Preliminary study. Equine Vet. J. 2008, 40, 178-181. [CrossRef] [PubMed]

44. Vizoso, F.J.; Eiro, N.; Cid, S.; Schneider, J.; Perez-Fernandez, R. Mesenchymal stem cell secretome: Toward cell-free therapeutic strategies in regenerative medicine. Int. J. Mol. Sci. 2017, 18, 1852. [CrossRef] [PubMed]

45. Klymiuk, M.C.; Balz, N.; Elashry, M.I.; Heimann, M.; Wenisch, S.; Arnhold, S. Exosomes isolation and identification from equine mesenchymal stem cells. BMC Vet. Res. 2019, 15, 42. [CrossRef] [PubMed]

46. Akyurekli, C.; Le, Y.; Richardson, R.B.; Fergusson, D.; Tay, J.; Allan, D.S. A Systematic review of preclinical studies on the therapeutic potential of mesenchymal stromal cell-derived microvesicles. Stem Cell Rev. Rep. 2015, 11, 150-160. [CrossRef] [PubMed]

47. Wang, X.; Omar, O.; Vazirisani, F.; Thomsen, P.; Ekström, K. Mesenchymal stem cell-derived exosomes have altered microRNA profiles and induce osteogenic differentiation depending on the stage of differentiation. PLoS ONE 2018, 13, e0193059. [CrossRef] 
48. Biancone, L.; Bruno, S.; Deregibus, M.C.; Tetta, C.; Camussi, G. Therapeutic potential of mesenchymal stem cell-derived microvesicles. Nephrol. Dial. Transplant. 2012, 27, 3037-3042. [CrossRef]

49. Gong, M.; Yu, B.; Wang, J.; Wang, Y.; Liu, M.; Paul, C.; Millard, R.W.; Xiao, D.-S.; Ashraf, M.; Xu, M. Mesenchymal stem cells release exosomes that transfer miRNAs to endothelial cells and promote angiogenesis. Oncotarget 2017, 8, 45200-45212. [CrossRef] 